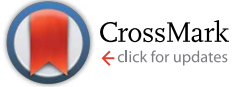

Cite this: J. Mater. Chem. A, 2014, 2 , 19201

Received 28th August 2014 Accepted 3rd October 2014

DOI: $10.1039 / c 4 t a 04459 b$

www.rsc.org/MaterialsA

\section{Organic photovoltaic cells utilising ZnO electron extraction layers produced through thermal conversion of $\mathrm{ZnSe} \dagger$}

\author{
Edward New, ${ }^{a}$ Ian Hancox, ${ }^{a}$ Luke A. Rochford, ${ }^{a}$ Marc Walker, ${ }^{b}$ Chloe Argent Dearden, ${ }^{a}$ \\ Chris F. McConville ${ }^{b}$ and Tim. S. Jones ${ }^{\star a}$
}

\begin{abstract}
In this work, a thin ZnSe layer was deposited in a vacuum and then thermally annealed in air to provide an efficient electron extraction layer for an inverted organic photovoltaic (OPV) cell. Annealing the ZnSe film at $\left.450{ }^{\circ} \mathrm{C}\left(\mathrm{ZnSe}_{(450}{ }^{\circ} \mathrm{C}\right)\right)$ increased the device performance and gave an efficiency of $2.83 \%$. X-ray photoelectron spectroscopy (XPS) measurements show that the increased device performance upon annealing at $450{ }^{\circ} \mathrm{C}$ is due to the thermal conversion of $\mathrm{ZnSe}$ to $\mathrm{ZnO}$. ZnO has a wider band gap than $\mathrm{ZnSe}$, which allows for more light to reach the photoactive layer. The electronic structures of the treated ZnSe films were explored by ultraviolet photoemission spectroscopy (UPS) which showed that the $\mathrm{ZnSe}_{\left(4500^{\circ} \mathrm{C}\right)}$ films had a Fermi level close to the conduction band edge, allowing for efficient electron extraction compared to the energetic barrier for extraction formed at the $\mathrm{ZnSe}_{(\mathrm{RT})} /$ organic interface.
\end{abstract}

\section{Introduction}

Organic photovoltaic (OPV) cells have received significant attention as an alternative renewable energy source due to their potential for low cost fabrication and fast energy payback times. ${ }^{1}$ In recent years efficiencies have risen above the $10 \%$ barrier using many different architectures and materials, with the record power conversion efficiency of $12 \%$ achieved for a multi-junction device. ${ }^{2}$ As well as improving the design of photoactive materials to enable higher photocurrents, the design of the interlayers is important for maximising the builtin field and providing lossless extraction at the organic/electrode interface.,4 These layers facilitate electron or hole extraction to the respective electrodes.

Hole extraction layers typically consist of either solution processed poly(3,4-ethylenedioxythiophene):poly(styrenesulfonate) (PEDOT:PSS) or high work function metal oxides such as $\mathrm{MoO}_{x}$, $\mathrm{V}_{2} \mathrm{O}_{x}, \mathrm{WO}_{x}$, which can be deposited either by vacuum deposition or solution methods. ${ }^{5-11}$ For electron extraction, most small molecule OPV devices use an organic exciton blocking layer such as bathocuproine (BCP), which transports charge through metal defects caused by cathode deposition. ${ }^{12,13}$ Other electron extraction layers used include low work function metal oxides such as $\mathrm{TiO}_{x}$ and $\mathrm{ZnO}$, which have high stability and high electron mobility. ${ }^{\mathbf{1 4 - 1 8}}$ These can be processed by many different

${ }^{a}$ Department of Chemistry, University of Warwick, Coventry, CV4 7AL, UK. E-mail: t.s. jones@warwick.ac.uk

${ }^{b}$ Department of Physics, University of Warwick, Coventry, CV4 7AL, UK

$\dagger$ Electronic supplementary information (ESI) available: Additional cell data, UPS valence band spectra and XPS spectra. See DOI: 10.1039/c4ta04459b methods including; solution from nanoparticles, sol-gel, electrodeposition, pulsed laser deposition and atomic layer deposition. ${ }^{19-24}$ Whilst these approaches are all capable of producing efficient electron extraction layers for OPVs, they each have drawbacks. Control and reproducibility to sub nanometre accuracy is hard to achieve with layers prepared from nanoparticles and sol-gels. Additionally, these solution processed methods require further optimisation for changes in laboratory temperature and humidity, which may also vary during a single day, as well as with substrate surface conditions. Pulsed laser deposition can suffer from small areas of uniformity and requires careful control of several parameters during growth. Thermal evaporation would be an alternative method to deposit such interfacial layers with sub nanometre accuracy, with film homogeneity across a wide area and without dependence on laboratory conditions. Thermal evaporation of interlayers would also allow reproducible scale-up of layer fabrication as well as the ability to deposit through shadow masks, for more complex modular structures. However, the high evaporation temperatures of both $\mathrm{ZnO}$ and $\mathrm{TiO}_{x}$ prevent common use by vacuum deposition in conjunction with small molecule vacuum evaporated OPVs. Using other chalcogenide derivatives of $\mathrm{Zn}$, such as ZnS and ZnSe which have lower evaporation temperatures, would allow for a wide band gap, low work function material to be thermally evaporated. By using the same process as the organic layers, a high degree of control over layer thickness and homogeneity can be obtained. Recent work has used vacuum deposition of $\mathrm{ZnS}$ as an electron extraction layer, although it requires the use of an $\mathrm{Al}_{2} \mathrm{~S}_{3}$ dopant for application in OPV cells. ${ }^{25}$ 
In this paper we have investigated the deposition of thin ZnSe layers by thermal evaporation in vacuum. The layers were subsequently heat treated under ambient conditions at a range of temperatures before inclusion in inverted small molecule OPV cells. The variation of cell performance with heat treatment temperature was investigated in terms of layer stoichiometry, electronic structure and surface morphology. The favourable change in electronic structure with heating at $450{ }^{\circ} \mathrm{C}$ was due to the thermal conversion of the ZnSe interlayer to $\mathrm{ZnO}$, resulting in a highly transparent, low work function electron extraction layer. This method of producing a thin, homogeneous ZnO layer led to improved efficiency for inverted device structures and can potentially be applied to other solar and organic electronic applications.

\section{Experimental}

ZnSe (Sigma Aldrich, 99.99\%) films were produced by vacuum evaporation on indium tin oxide (ITO) covered glass substrates (15 $\Omega \mathrm{sq}^{-1}$, Thin Film Devices) using a Kurt J. Lesker Spectros system with a base pressure of $1 \times 10^{-8}$ mbar. Each ZnSe film was then thermally annealed in air for $30 \mathrm{~min}$. For OPV device fabrication, the annealed ZnSe films were placed back in the vacuum chamber for subsequent deposition of organic layers. Of the organic materials used in these experiments, $\mathrm{C}_{60}$ (Nano-C Inc, $99.5 \%$ ) was purified by vacuum gradient sublimation prior to deposition, whilst boron subphthalocyanine chloride (SubPc, Lumtec, 99\%) and molybdenum oxide $\left(\mathrm{MoO}_{x}\right.$, Aldrich, 99.99\%) were used as received. The Al cathode was deposited in situ through a shadow mask, giving devices with an active area of $0.16 \mathrm{~cm}^{2}$. Where direct comparisons between electron extracting layer treatments are made, the common layers in all cells within the data set were deposited simultaneously to avoid batch-to-batch variations.

The current-voltage $(J-V)$ characteristics of the OPV cells were measured under simulated AM1.5G solar illumination at $100 \mathrm{~mW} \mathrm{~cm}^{-2}$ from a Newport Oriel solar simulator using a Keithley 2400 sourcemeter for current detection.

The X-ray photoelectron spectroscopy (XPS) measurements were carried out following transfer through air and loading into a UHV system with a base pressure of $\sim 2 \times 10^{-11} \mathrm{mbar}$. The sample was excited with X-rays from a monochromated $\mathrm{Al} \mathrm{k \alpha}$ source ( $h \nu=1486.6 \mathrm{eV}$ ), with the photoelectrons being detected at normal emission using an Omicron Sphera 7 channel concentric hemispherical electron analyser. The combined energy resolution of the experiment was calculated to be $0.47 \mathrm{eV}$ based on calibration scans with a polycrystalline Ag sample.

Ultra-violet photoemission spectroscopy (UPS) measurements were carried out using a custom multi-chamber ultrahigh vacuum (UHV) system with a base pressure of $\sim 1 \times 10^{-10}$ mbar. UPS spectra were recorded using a SPECS PHOIBOS 100 hemispherical electron energy analyser with excitation at $21.21 \mathrm{eV}$ from a He I gas discharge source.

Atomic force microscopy (AFM) images were obtained from an Asylum Research MFP-3D (Santa Barbara, USA) in AC mode, using AC240TS cantilevers.

\section{Results and discussion}

\section{OPV cells incorporating ZnSe layers}

The device structure of the inverted OPV cell used in this study is shown in Fig. 1a. The optimised structure comprised of ITO/ $\mathrm{ZnSe}_{\left({ }^{\circ}{ }^{\circ} \mathrm{C}\right)}(8 \mathrm{~nm}) / \mathrm{C}_{60}(35 \mathrm{~nm}) / \mathrm{SubPc}(14 \mathrm{~nm}) / \mathrm{MoO}_{x}(15 \mathrm{~nm}) / \mathrm{Al}$, where $\left.\operatorname{ZnSe}_{(x} \quad{ }^{\circ} \mathrm{C}\right)$ refers to the post deposition annealing temperatures, which were carried out at $250{ }^{\circ} \mathrm{C}, 350{ }^{\circ} \mathrm{C}$ and $450^{\circ} \mathrm{C}$, whilst also compared to an as-deposited layer (RT). The $J-V$ characteristic plots for the OPV cells with a range of $\mathrm{ZnSe}$ annealing temperatures are shown in Fig. 1b, with the performance parameters summarised in Table 1 (additional cell data shown in ESI Fig. S1 $\dagger)$. The $\mathrm{ZnSe}_{(\mathrm{RT})}$ cell displays a very poor efficiency of $0.03 \%$ and the low performance parameters are illustrated by the S-shape $J-V$ curve reducing dramatically before $J_{\mathrm{SC}}$. This is indicative of a blocking barrier to electron extraction and results in a high series resistance $\left(R_{\mathrm{S}}\right)^{26,27}$ Annealing the ZnSe layer considerably increases the photocurrent, with the $\mathrm{ZnSe}_{\left(250{ }^{\circ} \mathrm{C}\right)}$ and $\left.\mathrm{ZnSe}_{(350}{ }^{\circ} \mathrm{C}\right)$ cells having a $J_{\mathrm{SC}}$ of $3.22 \mathrm{~mA} \mathrm{~cm}^{-2}$ and $3.75 \mathrm{~mA} \mathrm{~cm}{ }^{-2}$ respectively. The performance of these cells is still hampered by the drop off in photocurrent after $J_{\mathrm{SC}}$ and low $V_{\mathrm{OC}}$ values of $0.44 \mathrm{~V}$ and $0.50 \mathrm{~V}$ respectively. The low currents in the $J-V$ plot after $V_{\mathrm{OC}}$ of these cells suggest there is a barrier for injection at the $\left.\mathrm{ITO} / \mathrm{ZnSe}_{(250}{ }^{\circ} \mathrm{C} / 350{ }^{\circ} \mathrm{C}\right)$ interface. ${ }^{26,27}$ The $\left.\mathrm{ZnSe}_{(450}{ }^{\circ} \mathrm{C}\right)$ cell shows the highest performance of all of the devices with an efficiency of $2.83 \%$. All of the device parameters are also improved with a high $V_{\mathrm{OC}}$ of $1.02 \mathrm{~V}$

a)
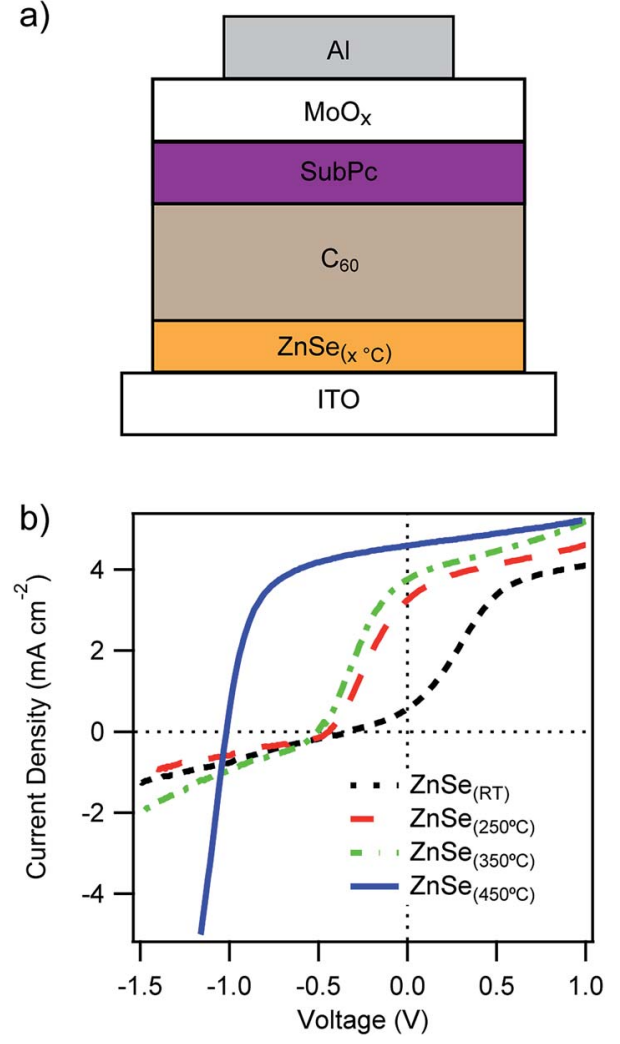

Fig. 1 (a) A schematic of the OPV cell design. (b) J-V characteristic plots for the different $\mathrm{ZnSe}$ annealing temperatures. 
Table 1 OPV cell performance parameters for each annealing temperature, averaged over a minimum of 6 devices fabricated simultaneously with standard deviations in parentheses

\begin{tabular}{|c|c|c|c|c|}
\hline ZnSe layer treatment & $J_{\mathrm{SC}}\left(\mathrm{mA} \mathrm{cm}^{-2}\right)$ & $V_{\mathrm{OC}}(\mathrm{V})$ & $\mathrm{FF}$ & $\eta(\%)$ \\
\hline $\mathrm{ZnSe}_{(\mathrm{RT})}$ & $0.53( \pm 0.13)$ & $0.33( \pm 0.04)$ & $0.19( \pm 0.01)$ & $0.03( \pm 0.01)$ \\
\hline $\mathrm{ZnSe}_{\left(250^{\circ} \mathrm{C}\right)}$ & $3.22( \pm 0.23)$ & $0.44( \pm 0.04)$ & $0.27( \pm 0.01)$ & $0.39( \pm 0.07)$ \\
\hline $\mathrm{ZnSe}_{\left(450{ }^{\circ} \mathrm{C}\right)}{ }^{a}$ & $4.59( \pm 0.03)$ & $1.02( \pm 0.00)$ & $0.59( \pm 0.01)$ & $2.83( \pm 0.04)$ \\
\hline
\end{tabular}

${ }^{a} \mathrm{ZnSe}_{\left(450{ }^{\circ} \mathrm{C}\right)}$ cell after $2 \mathrm{~min}$ AM1.5G $100 \mathrm{~mW} \mathrm{~cm}{ }^{-2}$ light soak. ${ }^{28,29}$

and a large FF of 0.59 achieved. The $\left.\mathrm{ZnSe}_{(450}{ }^{\circ} \mathrm{C}\right)$ cell also displayed the highest photocurrent of the ZnSe treatments, with $4.59 \mathrm{~mA} \mathrm{~cm}{ }^{-2}$, an improvement of $\sim 20 \%$ over the $\mathrm{ZnSe}_{\left(350{ }^{\circ} \mathrm{C}\right)}$ cell. The optimum efficiency was achieved after 2 minutes of light soaking to improve the series resistance, a phenomenon which has been observed previously in metal chalcogenide interlayers. ${ }^{28,29}$ The efficiency of this device is comparable to typical $\mathrm{SubPc} / \mathrm{C}_{60}$ regular architectures with a $\mathrm{MoO}_{x}$ hole extraction layer. ${ }^{30}$ Annealing the ZnSe to a higher temperature of $550{ }^{\circ} \mathrm{C}$ had a detrimental effect upon device performance (ESI Fig. S2†).

The transmittance spectra of $\left.80 \mathrm{~nm} \mathrm{ZnSe}_{(\mathrm{RT})}, \mathrm{ZnSe}_{(250}{ }^{\circ} \mathrm{C}\right)$, $\mathrm{ZnSe}_{\left(350{ }^{\circ} \mathrm{C}\right)}$ and $\mathrm{ZnSe}_{\left(450{ }^{\circ} \mathrm{C}\right)}$ films on quartz substrates are displayed in Fig. 2, with thicker layers used to obtain the bandgap $\left(E_{\mathrm{g}}\right)$ of each. There is a large difference in transmittance of the films, with those treated at room temperature to $350{ }^{\circ} \mathrm{C}$ absorbing strongly below $500 \mathrm{~nm}$ and more weakly in the red part of the spectrum, whereas the $\left.\mathrm{ZnSe}_{(450}{ }^{\circ} \mathrm{C}\right)$ film is highly transmissive in the visible range above $350 \mathrm{~nm}$. This change in transmittance with thermal annealing of the ZnSe can also be seen in the inset photograph in Fig. 2, with the $\mathrm{ZnSe}_{(\mathrm{RT})}$, $\mathrm{ZnSe}_{\left(2500^{\circ} \mathrm{C}\right)}$ and $\mathrm{ZnSe}_{\left(3500^{\circ} \mathrm{C}\right)}$ films displaying a green colour but the $\mathrm{ZnSe}_{\left(450{ }^{\circ} \mathrm{C}\right)}$ film being highly transparent. The optical band gap of the two films can be estimated from the transmittance plot from the onset in absorption. This gives values of $2.4 \mathrm{eV}$ for the $\mathrm{ZnSe}_{(\mathrm{RT})}$ film and $3.1 \mathrm{eV}$ for the $\mathrm{ZnSe}_{\left(4500^{\circ} \mathrm{C}\right)}$ film, signifying a change in the film composition.

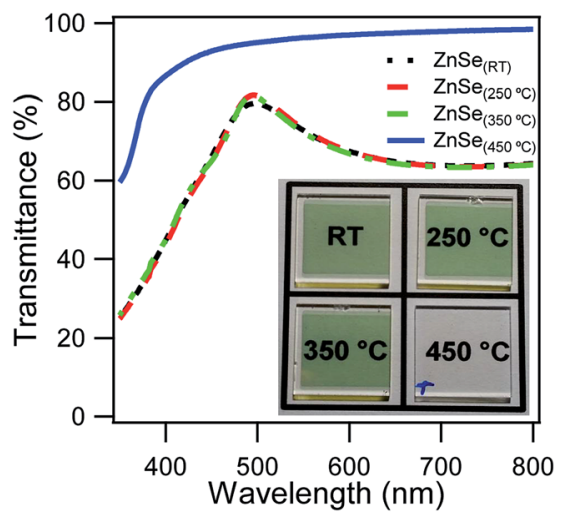

Fig. 2 Transmittance spectra of $80 \mathrm{~nm} \mathrm{ZnSe}\left(\mathrm{RT}_{)}, \mathrm{ZnSe}_{\left(250^{\circ} \mathrm{C}\right)}, \mathrm{ZnSe}_{\left(350^{\circ} \mathrm{C}\right)}\right.$ and $\left.\mathrm{ZnSe}_{(450}{ }^{\circ} \mathrm{C}\right)$ films on quartz substrates. Inset shows a photograph of the samples.

\section{Determination of ZnSe composition}

With the OPV cells fabricated with different ZnSe thermal treatments showing stark performance differences, alongside a significant change in transmittance, the factors influencing the changes were explored. XPS measurements were carried out in order to elucidate the effect of the heat treatment on the stoichiometry and composition of the films. XPS spectra displaying the Se $3 d$ and $O$ 1s regions of the films treated at each temperature are presented in Fig. 3 and 4 respectively. XPS spectra for the $\mathrm{Zn} 2 \mathrm{p}$ regions can be found in the ESI Fig. S3. $\dagger$ In

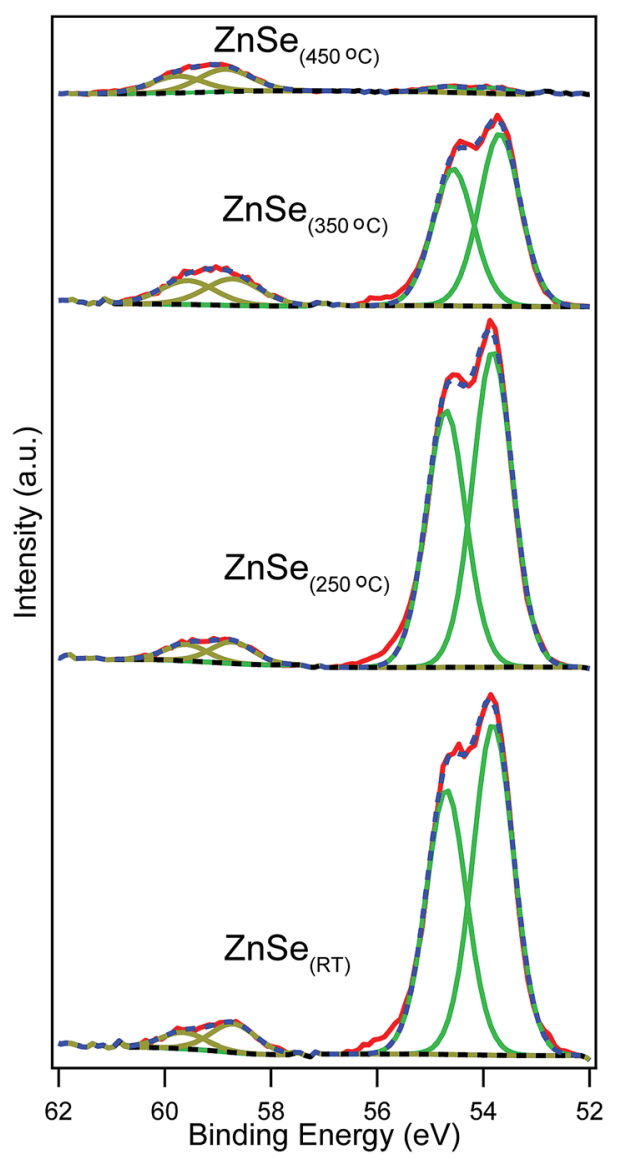

Fig. 3 XPS spectra of the Se 3d region obtained for each layer treatment. Red lines indicate experimental data, dashed black lines the Shirley backgrounds, dashed blue lines the fitting envelope, with gold and green lines representing the fitting for $\mathrm{SeO}_{2}$ and $\mathrm{ZnSe}$ environment contributions respectively. 


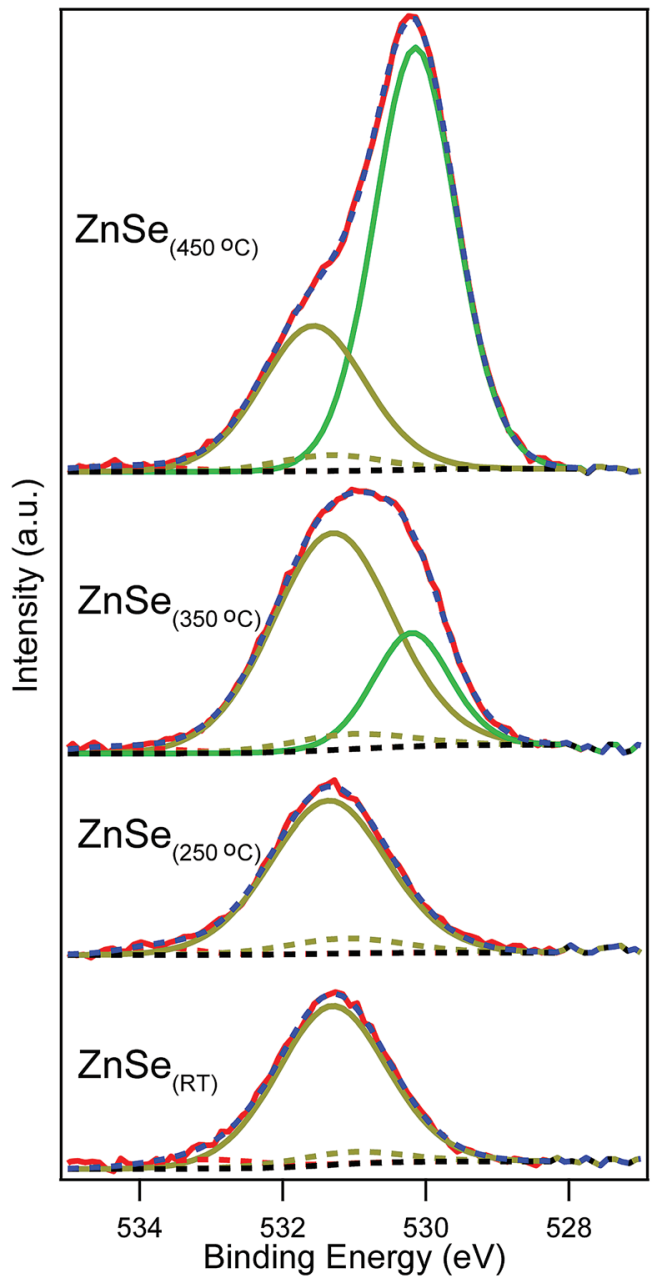

Fig. 4 XPS spectra of the $O$ 1s region obtained for each layer treatment. Red lines indicate experimental data, dashed black lines the Shirley backgrounds, dashed blue lines the fitting envelope, with gold solid and dotted lines representing the fitting for contaminant and $\mathrm{SeO}_{2}$ respectively, red dotted lines the water contribution and green lines representing the fitting for the $\mathrm{ZnO}$ environment contributions.

each instance, Shirley background subtractions were used with peaks fitted by a Lorentzian-Guassian combination, which was kept consistent for each treatment.

The Se 3d region shown in Fig. 3 displays two features, one centred at $59.0 \mathrm{eV}$ binding energy and the other at $54.0 \mathrm{eV}$. Each feature comprises two peaks due to the spin orbit splitting of the Se $3 \mathrm{~d}$ level. At every treatment temperature the magnitude of the feature at $59.0 \mathrm{eV}$ remains similar, with components at $59.6 \mathrm{eV}$ and $58.7 \mathrm{eV}$. These peaks can be attributed to the Se $3 \mathrm{~d}_{1 / 2}$ and $3 \mathrm{~d}_{3 / 2}$ levels in $\mathrm{SeO}_{2} \cdot{ }^{31}$ However, the contribution from the feature centred at $54.0 \mathrm{eV}$ varies greatly with film treatment. The $\mathrm{ZnSe}_{(\mathrm{RT})}$ and $\left.\mathrm{ZnSe}_{(250}{ }^{\circ} \mathrm{C}\right)$ layers show a large feature of similar dimensions. The peaks at $54.7 \mathrm{eV}$ and $53.8 \mathrm{eV}$ binding energy are due to the $3 \mathrm{~d}_{1 / 2}$ and $3 \mathrm{~d}_{3 / 2}$ splitting of the Se $3 \mathrm{~d}$ attributed to $\mathrm{ZnSe}^{31}$ For the $\left.\mathrm{ZnSe}_{(350}{ }^{\circ} \mathrm{C}\right)$ layers the magnitude of the feature is noticeably smaller, and for $\left.\mathrm{ZnSe}_{(450}{ }^{\circ} \mathrm{C}\right)$ layers the feature is almost negligible. This would suggest that the films treated at higher temperatures have significantly decreased ZnSe content.

In order to further investigate this change in stoichiometry on thermal processing, a spectrum of the $\mathrm{O} 1 \mathrm{~s}$ region for each layer was obtained, and is shown in Fig. 4. The $\mathrm{ZnSe}_{(\mathrm{RT})}$ and $\mathrm{ZnSe}_{\left(250{ }^{\circ} \mathrm{C}\right)}$ layers show only two major components in the $\mathrm{O} 1 \mathrm{~s}$ region, centred at $531.3 \mathrm{eV}$ and $531.1 \mathrm{eV}$, which are due to contaminants and $\mathrm{SeO}_{2}$ respectively. ${ }^{31} \mathrm{~A}$ further smaller component is shown at $\sim 534.0 \mathrm{eV}$ for each case due to water on the surface. For $\mathrm{ZnSe}_{\left(350{ }^{\circ} \mathrm{C}\right)}$ layers, an additional peak is shown at $530.2 \mathrm{eV}$ which is attributed to the presence of $\mathrm{ZnO}$. For the $\left.\mathrm{ZnSe}_{(450}{ }^{\circ} \mathrm{C}\right)$ layers, the $\mathrm{ZnO}$ feature at $530.2 \mathrm{eV}$ becomes dominant. Since the Se $3 d$ region indicated only a small fraction of the $\mathrm{ZnSe}$ remained within the films treated at $450{ }^{\circ} \mathrm{C}$, this would suggest that the $\mathrm{ZnSe}_{\left(450^{\circ} \mathrm{C}\right)}$ layer has been nearly fully converted to $\mathrm{ZnO}$ (we will continue to refer to the $\mathrm{ZnO}$ layer formed as $\mathrm{ZnSe}_{\left(450{ }^{\circ} \mathrm{C}\right)}$ for consistency). Thermal conversion of $\mathrm{ZnSe}$ to $\mathrm{ZnO}$ has been shown by annealing in air at $400-600{ }^{\circ} \mathrm{C}^{32}$ The reaction follows the equation:

$$
\mathrm{ZnSe}+\frac{3}{2} \mathrm{O}_{2} \rightarrow \mathrm{ZnO}+\mathrm{SeO}_{2}
$$

The $\mathrm{SeO}_{2}$ is gaseous so is driven off, leaving behind $\mathrm{ZnO}$ on the substrate.

To quantify the relative stoichiometry after each treatment condition, the relative sensitivity factors (rsf) for each component were utilised. Table 2 displays the relative composition found for each environment from the XPS spectra. The percentage fraction of $\mathrm{SeO}_{2}$ is also shown. The $\mathrm{ZnSe}_{(\mathrm{RT})}$ and $\mathrm{ZnSe}_{\left(250^{\circ} \mathrm{C}\right)}$ layers contain negligible $\mathrm{ZnO}$, with $\mathrm{ZnSe}$ in a $\mathrm{Zn}$ : Se ratio of $0.86: 1$ and $0.93: 1$ respectively. This indicates that the $\mathrm{ZnSe}$ layers are slightly Se rich. Treatment at $350{ }^{\circ} \mathrm{C}$ results in a layer composed of both $\mathrm{ZnSe}$ and $\mathrm{ZnO}$. The ratio of Se $3 \mathrm{~d}$ $(\mathrm{ZnSe}): \mathrm{O} 1 \mathrm{~s}(\mathrm{ZnO})$ is shown to be $1.27: 1$. Therefore, nearly half of the $\mathrm{ZnSe}$ in the layer is converted to $\mathrm{ZnO}$. The $\left.\mathrm{ZnSe}_{(450}{ }^{\circ} \mathrm{C}\right)$ layer only contains $0.6 \% \mathrm{ZnSe}$ content from the Se $3 \mathrm{~d}$ region. However, $\mathrm{ZnO}$ is present in a $\mathrm{Zn}: \mathrm{O}$ ratio of $0.83: 1$. Thus, the heat treatment at this temperature produces an oxygen rich $\mathrm{ZnO}$ film.

These changes in layer composition with heat treatment help explain the widening of the bandgap, $E_{\mathrm{g}}$, from $2.4 \mathrm{eV}$ for $\mathrm{ZnSe}_{(\mathrm{RT})}$ to $3.1 \mathrm{eV}$ for $\left.\mathrm{ZnSe}_{(450}{ }^{\circ} \mathrm{C}\right)$. However, $\mathrm{ZnSe}$ is known to exhibit a much smaller $E_{\mathrm{g}}$ than $\mathrm{ZnO}$ when each material is deposited via other methods, hence the widening of the $E_{\mathrm{g}}$ on heat treatment due to conversion from $\mathrm{ZnSe}$ to $\mathrm{ZnO}$ is to be expected. ${ }^{3,33}$ The additional transparency of the wide band gap $\left.\mathrm{ZnSe}_{(450}{ }^{\circ} \mathrm{C}\right) \mathrm{film}$ is beneficial for use as an electron extracting layer, allowing the increase in cell $J_{\mathrm{SC}}$ shown in Table 1.

\section{Electronic structure of the ZnSe films}

The electronic structure of an electron extracting layer can also have a major influence on the cell performance as displayed in Fig. $1 .^{34,35}$ In order to maximise the built-in field $\left(V_{\mathrm{bi}}\right)$ of the OPV cell, thus minimising losses in $V_{\mathrm{OC}}$, the interfacial contacts either side of the photoactive material must have favourable 
Table 2 Table showing the layer composition for each treatment of the near surface region, obtained through fitting of XPS data in combination with the rsf of each component

\begin{tabular}{|c|c|c|c|c|}
\hline $\mathrm{ZnSe}_{(\mathrm{RT})}$ & 49.9 & 4.1 & 0.0 & 43.0 \\
\hline $\mathrm{ZnSe}_{\left(350{ }^{\circ} \mathrm{C}\right)}$ & 23.3 & 5.1 & 18.4 & 49.4 \\
\hline $\mathrm{ZnSe}_{\left(4500^{\circ} \mathrm{C}\right)}$ & 0.6 & 2.7 & 51.5 & 42.7 \\
\hline
\end{tabular}

energetic alignment with the corresponding organic. This is described elegantly by the integer charge model proposed by Crispin et al. and Braun et al. ${ }^{36,37}$ In the case of hole extracting materials, such as the $\mathrm{MoO}_{x}$ layer used in cells here, the work function must be larger than the positive integer charge transfer (ICT) state of the donor organic. ${ }^{30}$ This is typically $0.1-0.3 \mathrm{eV}$ above the highest occupied molecular orbital (HOMO) onset for the organic material. For the electron extracting material, the work function of the interlayer must be smaller than the negative ICT of the acceptor organic, typically $0.1-0.3 \mathrm{eV}$ below the lowest unoccupied molecular orbital (LUMO) of the organic. The commonly used fullerene acceptor materials employed in OPV cells are $\mathrm{C}_{60}$ (LUMO - 4.4 to $4.5 \mathrm{eV}$ ) and PCBM (LUMO $4.3 \mathrm{eV}) .{ }^{38-40}$ In addition, to extract charges efficiently the position of the conduction band $(\mathrm{CB})$ in relation to the organic acceptor materials LUMO needs to be considered. If there is an energetic barrier to electron extraction then the layer will be detrimental to cell performance..$^{26,27}$

UPS measurements were obtained in order to probe the electronic structure of the interface between the ZnSe layers and the organic acceptor material. The secondary electron cut-off and valence band UPS spectra shown in Fig. 5 were used to determine the electronic properties of the $\mathrm{ZnSe}_{(\mathrm{RT})}$ and $\mathrm{ZnSe}_{\left(4500^{\circ} \mathrm{C}\right)}$ layers. Valence band spectra for $\left.\mathrm{ZnSe}_{(250}{ }^{\circ} \mathrm{C}\right)$ and $\left.\mathrm{ZnSe}_{(350}{ }^{\circ} \mathrm{C}\right)$ layers are shown in ESI Fig. S4. $\dagger$ In Fig. 5a, the secondary electron cut-off region indicates the work function of each sample. The work function of the $\mathrm{ZnSe}_{(\mathrm{RT})}$ layer was found to be $3.6 \mathrm{eV}$, whilst $\left.\mathrm{ZnSe}_{(450}{ }^{\circ} \mathrm{C}\right)$ layers possess a work function of $3.4 \mathrm{eV}$. This indicates that both layers have a favourable work function for use as electron extracting materials.

A more significant difference between the treatments is expressed in the valence band (VB) UPS spectra, shown in Fig. 5b. The untreated ZnSe layer (black line) has a valence band onset $1.1 \mathrm{eV}$ below the Fermi level, yielding an ionization potential (IP) of $4.7 \mathrm{eV}$. With the position of the VB determined, we can use the optical band gap measurement to predict the position of the $\mathrm{CB}$ of the material. Therefore, the band gap of $2.4 \mathrm{eV}$ indicates the electron affinity (EA) of the $\mathrm{ZnSe}_{(\mathrm{RT})}$ is $2.3 \mathrm{eV}$. Due to the positioning of the valence band in relatively close proximity to the Fermi level $\left(E_{\mathrm{F}}\right)$ in $\mathrm{ZnSe}_{(\mathrm{RT})}$, the layer will be unable to block holes from the HOMO of the organic layers. This would lead to detrimental quenching of excitons at this interface. More significantly, the $\mathrm{CB}$ of $\mathrm{ZnSe}_{(\mathrm{RT})}$ is $1.3 \mathrm{eV}$ above the $E_{\mathrm{F}}$ of the layer. Therefore, a large energetic barrier to electron extraction from the organic LUMO is formed at the interface. This is shown with comparison to literature values for the electronic structure of $\mathrm{C}_{60}$ in Fig. 6a, indicating a barrier of $0.8 \mathrm{eV} .^{40}$ This energetic barrier to electron extraction explains the poor electron extracting characteristics of the $\mathrm{ZnSe}_{(\mathrm{RT})}$ layer, and consequently is the cause of the inefficient OPV cell performance shown in Fig. $1 \mathrm{~b}$.

In stark contrast, the valence band onset of the layer treated at $450{ }^{\circ} \mathrm{C}$ (blue line) is $3.3 \mathrm{eV}$ below the $E_{\mathrm{F}}$ of the $\mathrm{ZnSe}_{\left(450{ }^{\circ} \mathrm{C}\right)}$ layer
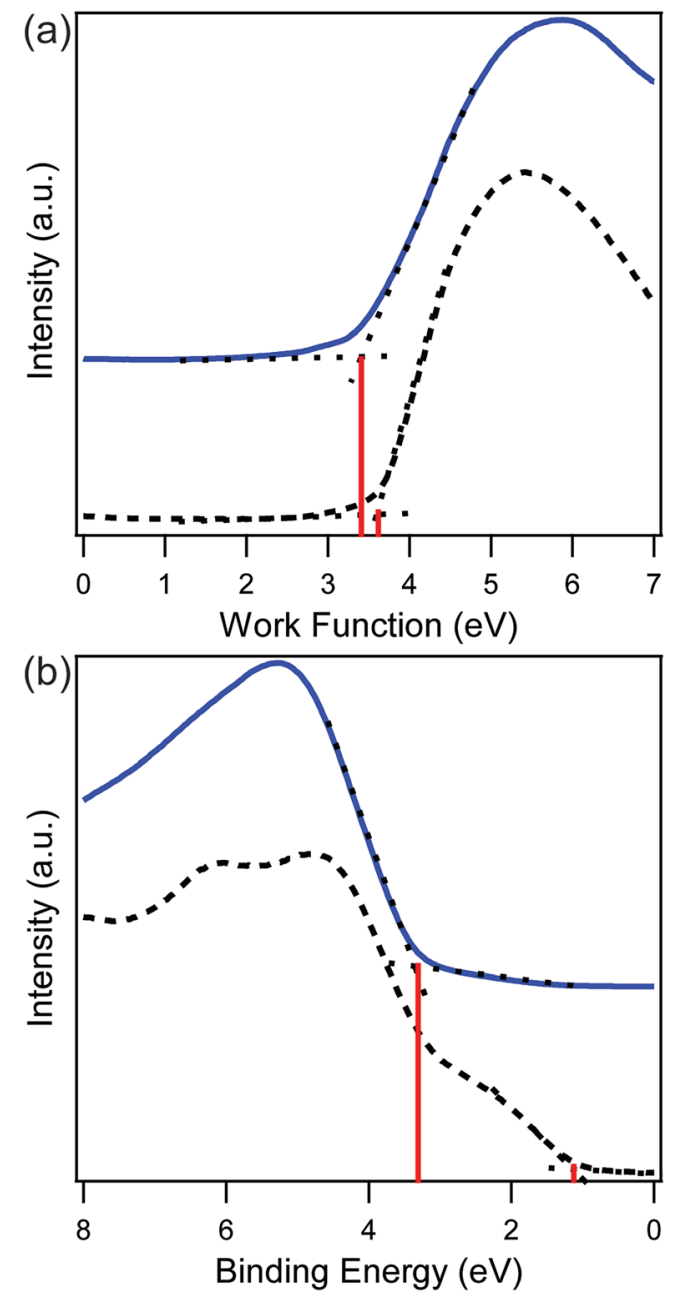

Fig. 5 Onset of the secondary electron cut-off (a) and valence band

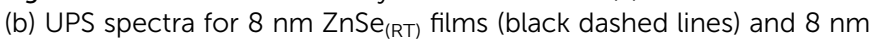
$\mathrm{ZnSe}_{\left(450^{\circ} \mathrm{C}\right)}$ films (blue solid lines), both deposited onto ITO substrates. Solid red and dashed black lines show fitting of the data. 
(a)

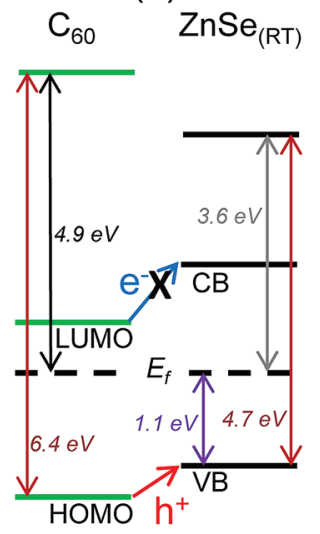

(b)

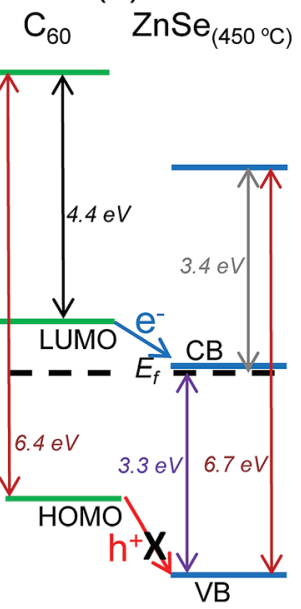

Fig. 6 Schematic of hole extraction routes at the $\mathrm{C}_{60}$ /electron extracting interface for $\mathrm{ZnSe}_{(\mathrm{RT})}$ (a) and $\mathrm{ZnSe}_{\left(450^{\circ} \mathrm{C}\right)}$ (b) layers. Values for $\mathrm{C}_{60}$ electronic structure taken from measurements reported in literature. $^{40}$

(Fig. 5a). This indicates the material possesses an IP of $6.7 \mathrm{eV}$, forming a large energetic barrier to hole extraction at the interface with the organic acceptor. This favourable ability to block hole extraction is shown schematically in Fig. 6b, with an energetic barrier of $\sim 1.8 \mathrm{eV}$ when compared to the literature values for the electronic structure of $\mathrm{C}_{60} \cdot{ }^{40}$ The measurements also show a highly n-type character, with the $\mathrm{CB}$ of $\mathrm{ZnSe}_{\left(450{ }^{\circ} \mathrm{C}\right)}$ close to the $E_{\mathrm{F}}$ of the layer. This is unsurprising given previous reports of the electronic structure of $\mathrm{ZnO}$ films deposited via other methods. ${ }^{3,18}$ The position of the $\mathrm{CB}$ in $\mathrm{ZnSe}_{\left(450{ }^{\circ} \mathrm{C}\right)}$ layers allows energetically favourable electron extraction with $\mathrm{C}_{60}$ (Fig. 6b), hence the excellent OPV performance shown for deposition on $\left.\mathrm{ZnSe}_{(450}{ }^{\circ} \mathrm{C}\right)$ layers in Fig. 1 .

\section{Topography of the layers}

Surface morphology of the electron extracting layers may also influence cell performance. The surface topography of the layers was obtained using an AFM in AC mode, with the topographical images for $\mathrm{ZnSe}_{(\mathrm{RT})}$ and $\mathrm{ZnSe}_{\left(450{ }^{\circ} \mathrm{C}\right)}$ layers shown in Fig. 7. These

(a)

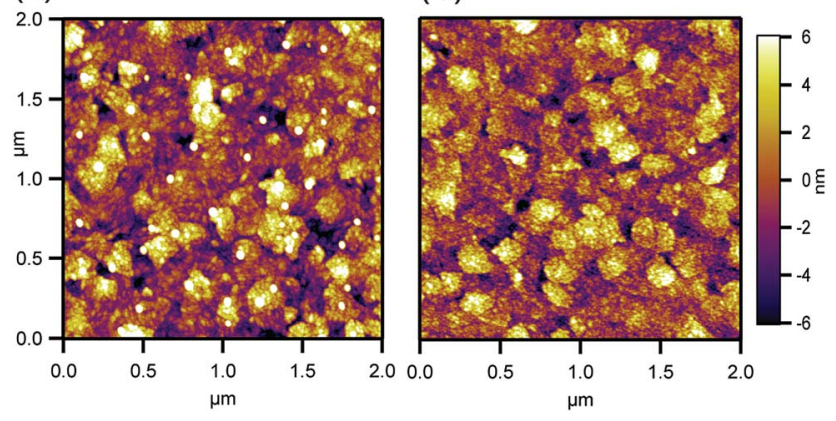

Fig. $72.0 \mu \mathrm{m}$ AFM topographical images of (a) ITO/ZnSe $\mathrm{IRT}_{(\mathrm{T})}$ and (b) $\mathrm{ITO} / \mathrm{ZnSe}\left(450^{\circ} \mathrm{C}\right)$, with the same height scale $( \pm 6 \mathrm{~nm})$. images show that the surface morphology of the layers differ, with surface roughness $\left(R_{\mathrm{q}}\right)$ values of $3.1 \mathrm{~nm}$ and $2.5 \mathrm{~nm}$ for $\mathrm{ZnSe}_{(\mathrm{RT})}$ and $\mathrm{ZnSe}_{\left(450{ }^{\circ} \mathrm{C}\right)}$ layers respectively. The $\mathrm{ZnSe}_{(\mathrm{RT})}$ film (Fig. 7a) shows a smooth surface with small 'dot' features up to $20 \mathrm{~nm}$ high and $80 \mathrm{~nm}$ wide, with an average density of $\mathbf{1 1 . 5}$ 'dots' $\mu \mathrm{m}^{-2}$. Even without taking tip convolution effects into account, these 'dots' only make up $\sim 4 \%$ of the volume of the 8 $\mathrm{nm}$ ZnSe film deposited on the ITO surface. Upon heat treatment at $450{ }^{\circ} \mathrm{C}$ the 'dots' are no longer present (Fig. 7b), leading to the lower $R_{\mathrm{q}}$ values obtained. However, since both layers provide a relatively smooth surface, the morphologies should not influence OPV device performance greatly, especially in comparison to the differences in the electronic properties of the layers.

\section{Conclusions}

This work has focused on the fabrication of thermally evaporated electron extracting materials based on $\mathrm{ZnSe}$ for use in OPV cells. Thin layers of ZnSe were grown and heat treated prior to use in OPV cells. The OPV cell performance was found to dramatically increase upon heat treatment of the ZnSe electron extraction layer from $0.03 \%$ for cells on the $\mathrm{ZnSe}_{(\mathrm{RT})}$ layers, to $2.83 \%$ on the $\left.\mathrm{ZnSe}_{(450}{ }^{\circ} \mathrm{C}\right)$ layer. The widening of the $E_{\mathrm{g}}$ featured in the transmittance when comparing $\mathrm{ZnSe}_{(\mathrm{RT})}$ to $\left.\mathrm{ZnSe}_{(450}{ }^{\circ} \mathrm{C}\right)$ layers was shown to be due to the thermal oxidation of $\mathrm{ZnSe}$ to $\mathrm{ZnO}$. While the UPS measurements indicate that both $\mathrm{ZnSe}_{(\mathrm{RT})}$ and $\left.\mathrm{ZnSe}_{(450}{ }^{\circ} \mathrm{C}\right)$ layers have low work functions that are favourable for electron extracting materials, the position of the $\mathrm{VB}$ and $\mathrm{CB}$ for each layer influences cell performance. The position of the $\mathrm{CB}$ for the $\mathrm{ZnSe}_{(\mathrm{RT})}$ layer causes an energetic barrier to electron extraction, whereas the close proximity of the $\mathrm{CB}$ to the $E_{\mathrm{F}}$ in $\left.\mathrm{ZnSe}_{(450}{ }^{\circ} \mathrm{C}\right)$ films allows efficient extraction. This results in poor OPV cell performances when using $\mathrm{ZnSe}_{(\mathrm{RT})}$ layers, but efficient performances upon heat treatment to form $\mathrm{ZnSe}_{\left(450{ }^{\circ} \mathrm{C}\right)}$ electron extracting layers. This approach allows for sub nanometre control over interfacial layer thickness and due to the ease of thermal deposition and heat treatment, these films show promise as possible electron extracting layers during the scale up of OPV manufacture and for use in other organic electronic applications.

\section{Notes}

The authors declare no competing financial interest.

\section{Acknowledgements}

E. New and I. Hancox are supported by TSB project "Development of Prototype High Efficiency Multi-Junction Organic Solar Cells (\#100900). The XPS system used in this research was funded through the Science City Research Alliance (SCRA) Advanced Materials Project 1: "Creating and Characterizing Next Generation of Advanced Materials" with support from Advantage West Midlands (AWM) and the European Regional Development Fund (ERDF). 


\section{References}

1 N. Espinosa, M. Hosel, D. Angmo and F. C. Krebs, Energy Environ. Sci., 2012, 5, 5117-5132.

2 Heliatek Press Release 16/01/2013, http://www.heliatek.com, accessed 9 April 2014.

3 M. T. Greiner, M. G. Helander, W. M. Tang, Z. B. Wang, J. Qiu and Z. H. Lu, Nat. Mater., 2012, 11, 76-81.

4 I. Hancox, L. A. Rochford, D. Clare, M. Walker, J. J. Mudd, P. Sullivan, S. Schumann, C. F. McConville and T. S. Jones, J. Phys. Chem. C, 2013, 117, 49-57.

5 Y. Kim, A. M. Ballantyne, J. Nelson and D. D. C. Bradley, Org. Electron., 2009, 10, 205-209.

6 V. Shrotriya, G. Li, Y. Yao, C. W. Chu and Y. Yang, Appl. Phys. Lett., 2006, 88, 073508.

7 I. Hancox, L. A. Rochford, D. Clare, P. Sullivan and T. S. Jones, Appl. Phys. Lett., 2011, 99, 013304.

8 M. Vasilopoulou, G. Papadimitropoulos, L. C. Palilis, D. G. Georgiadou, P. Argitis, S. Kennou, I. Kostis, N. Vourdas, N. A. Stathopoulos and D. Davazoglou, Org. Electron., 2012, 13, 796-806.

9 J. Meyer, S. Hamwi, M. Kroger, W. Kowalsky, T. Riedl and A. Kahn, Adv. Mater., 2012, 24, 5408-5427.

10 M. D. Irwin, B. Buchholz, A. W. Hains, R. P. H. Chang and T. J. Marks, Proc. Natl. Acad. Sci. U. S. A., 2008, 105, 27832787.

11 E. L. Ratcliff, J. Meyer, K. X. Steirer, A. Garcia, J. J. Berry, D. S. Ginley, D. C. Olson, A. Kahn and N. R. Armstrong, Chem. Mat., 2011, 23, 4988-5000.

12 B. P. Rand, J. Li, J. G. Xue, R. J. Holmes, M. E. Thompson and S. R. Forrest, Adv. Mater., 2005, 17, 2714-2718.

13 H. Gommans, B. Verreet, B. P. Rand, R. Muller, J. Poortmans, P. Heremans and J. Genoe, Adv. Funct. Mater., 2008, 18, 3686-3691.

14 J. Y. Kim, S. H. Kim, H. H. Lee, K. Lee, W. L. Ma, X. Gong and A. J. Heeger, Adv. Mater., 2006, 18, 572-576.

15 J. G. Li, S. Kim, S. Edington, J. Nedy, S. Cho, K. Lee, A. J. Heeger, M. C. Gupta and J. T. Yates, Sol. Energy Mater. Sol. Cells, 2011, 95, 1123-1130.

16 H. Kim, J. Hwa Seo and S. Cho, Appl. Phys. Lett., 2011, 99, 213302.

17 C. Waldauf, M. Morana, P. Denk, P. Schilinsky, K. Coakley, S. A. Choulis and C. J. Brabec, Appl. Phys. Lett., 2006, 89, 233517.

18 S. Schumann, R. Da Campo, B. Illy, A. C. Cruickshank, M. A. McLachlan, M. P. Ryan, D. J. Riley, D. W. McComb and T. S. Jones, J. Mater. Chem., 2011, 21, 2381-2386.

19 J. Gilot, I. Barbu, M. M. Wienk and R. A. J. Janssen, Appl. Phys. Lett., 2007, 91, 113520.
20 M. S. White, D. C. Olson, S. E. Shaheen, N. Kopidakis and D. S. Ginley, Appl. Phys. Lett., 2006, 89, 143517.

21 B. N. Illy, A. C. Cruickshank, S. Schumann, R. Da Campo, T. S. Jones, S. Heutz, M. A. McLachlan, D. W. McComb, D. J. Riley and M. P. Ryan, J. Mater. Chem., 2011, 21, 12949-12957.

22 J. B. Franklin, B. Zou, P. Petrov, D. W. McComb, M. P. Ryan and M. A. McLachlan, J. Mater. Chem., 2011, 21, 8178-8182.

$23 \mathrm{H}$. Cheun, C. Fuentes-Hernandez, Y. H. Zhou, W. J. Potscavage, S. J. Kim, J. Shim, A. Dindar and B. Kippelen, J. Phys. Chem. C, 2010, 114, 20713-20718.

24 C. A. Dearden, M. Walker, N. Beaumont, I. Hancox, N. K. Unsworth, P. Sullivan, C. F. McConville and T. S. Jones, Phys. Chem. Chem. Phys., 2014, 16, 18926-18932. 25 C. J. Traverse, M. Young, S. Wagner, P. Zhang, P. Askeland, M. C. Barr and R. R. Lunt, J. Appl. Phys., 2014, 115, 194505. 26 W. Tress, K. Leo and M. Riede, Adv. Funct. Mater., 2011, 21, 2140-2149.

27 W. Tress and O. Inganas, Sol. Energy Mater. Sol. Cells, 2013, 117, 599-603.

28 H. Schmidt, K. Zilberberg, S. Schmale, H. Flügge, T. Riedl and W. Kowalsky, Appl. Phys. Lett., 2010, 96, 243305.

29 J. Gilot, M. M. Wienk and R. A. J. Janssen, Appl. Phys. Lett., 2007, 90, 143512.

30 I. Hancox, P. Sullivan, K. V. Chauhan, N. Beaumont, L. A. Rochford, R. A. Hatton and T. S. Jones, Org. Electron., 2010, 11, 2019-2025.

31 M. Shenasa, S. Sainkar and D. Lichtman, J. Electron Spectrosc. Relat. Phenom., 1986, 40, 329-337.

32 K. Tomura, M. Ohnishi and M. Yoshizaw, Jpn. J. Appl. Phys., 1974, 13, 939-943.

33 C. D. Lokhande, P. S. Patil, H. Tributsch and A. Ennaoui, Sol. Energy Mater. Sol. Cells, 1998, 55, 379-393.

34 E. L. Ratcliff, B. Zacher and N. R. Armstrong, J. Phys. Chem. Lett., 2011, 2, 1337-1350.

35 R. Po, C. Carbonera, A. Bernardi and N. Camaioni, Energy Environ. Sci., 2011, 4, 285-310.

36 A. Crispin, X. Crispin, M. Fahlman, M. Berggren and W. R. Salaneck, Appl. Phys. Lett., 2006, 89, 213503.

37 S. Braun, W. R. Salaneck and M. Fahlman, Adv. Mater., 2009, 21, 1450-1472.

38 Y. Kim, M. Shin, I. Lee, H. Kim and S. Heutz, Appl. Phys. Lett., 2008, 92, 093306.

39 J. Y. Kim, K. Lee, N. E. Coates, D. Moses, T.-Q. Nguyen, M. Dante and A. J. Heeger, Science, 2007, 317, 222-225.

40 S. W. Cho, L. F. J. Piper, A. DeMasi, A. R. H. Preston, K. E. Smith, K. V. Chauhan, P. Sullivan, R. A. Hatton and T. S. Jones, J. Phys. Chem. C, 2010, 114, 1928-1933. 